\title{
MECHANICAL PROPERTIES OF THE GYPSUM COMPOSITE REINFORCEMENT WITH WOODEN FIBERS
}

\author{
MARKÉTA HOŠŤÁLKOVÁ* NIKOLA VAV̌̌ÍNOVÁ, VERONIKA LONGAUEROVÁ \\ Faculty of Civil Engineering, VŠB TUO, Ludvíka Podéště 1875/17, 708 33, Ostrava-Poruba, Czech Republic \\ *E-mail: marketa.hostalkova.st@vsb.cz
}

\begin{abstract}
The gypsum is one of the most often used materials in the civil engineering. Very often it is applied in the form of plasterboards without any reinforcement, for example, cladding boards are unusable as supporting construction. To improve the mechanical properties of plasterboards, fibrous materials such as cellulose or glass fiber are added. Reinforcement of gypsum with fibers improves in particular the flexural and shear strength. The main purpose of the research is to clarify whether natural wooden fibers could be used as the reinforced of composite gypsum building materials. Wooden fibers are used as a blown or board thermal insulation. This article presents the results of tests aimed at determining the mechanical and physical properties of gypsum composite reinforced with wooden fibers. The effect of the reinforcement on the strength properties as a compressive strength, flexural strength was verified on a series of test specimens. The results of the tests have shown that the reinforcing of gypsum composite has an impact on the mechanical-physical parameters.
\end{abstract}

Keywords: composite materials, plasterboards, reinforcement of natural fibers, wooden fibers

\section{Introduction}

Plaster fiber boards have a wide use in the construction industry. They can be used as construction boards for cladding the load-bearing walls of wooden constructions as an alternative to wood-based board OSB. Plaster fiber boards are used for fire-cladding of building structures and can be used in areas with high humidity. Wooden fibers have class of reaction to fire B2, according to DIN 4102-1 [1] and class of reaction to fire E, according to ČSN EN 13501-1 [2]. Compared with plasterboards, plaster fiber boards are flexible and have a higher hardness. Fiber is used as a reinforcement but mostly reduces their compressive strength. This article presents the results of tests aimed at determining the mechanical and physical properties of gypsum composite reinforced with wooden fibers. The effect of the reinforcement on the strength properties as a compressive strength, flexural strength was verified on a series of test specimens. The results of the tests have shown that the reinforcing of gypsum composite has an impact on the mechanical-physical parameters. The main purpose of the research is to clarify whether natural wooden fibers could be used as the reinforcement of composite gypsum building materials, because of its many advantages. One of them is that the wooden fibers are recyclable and their production has a negative residue of carbon dioxide release. As next, value of thermal conductivity $\lambda=0.038 \mathrm{~W} \cdot \mathrm{m}^{-1} \mathrm{~K}^{-1}$, (which is better than value of crushed straw, which is $\lambda=0.045 \mathrm{~W} \cdot \mathrm{m}^{-1} \mathrm{~K}^{-1}$ ) [3] showed that wooden fibers are very good as thermal insulator. Very interesting are the results of laboratory measurements of acoustic properties (laboratory value of airborne sound reduction index $R_{w}[\mathrm{~dB}]$ ) of peripheral load bearing construction of wooden buildings [4]. A great advantage of wooden fibers is their availability and applicability on buildings. It is possible to supply this material for the whole year. Wooden fibers may, in the future, be an economically advantageous, natural and environmentally friendly building material.

This is an open-access article distributed under the terms of the Creative Commons Attribution-NonCommercial 4.0 International License (https://creativecommons.org/licenses/by-nc/4.0/), which permits unrestricted use, distribution, and reproduction in any medium for non-commercial purposes, provided the original author and source are credited, a link to the CC License is provided, and changes - if any - are indicated. 


\section{Preparation of test specimens}

For production of test samples, building plaster and wooden fibers were selected.

The building plaster (bonding material) is a powdered mixture of hemihydrate of calcium sulphate $\left(\mathrm{CaSO}_{4} \cdot 0.5 \mathrm{H}_{2} \mathrm{O}\right)$ with strength $\mathrm{G} 2(2 \mathrm{MPa})$. The wooden fibers (filler) have been added in a percentage ratio to the mixture of plaster with $750 \mathrm{ml}$ of water $[5,6]$.

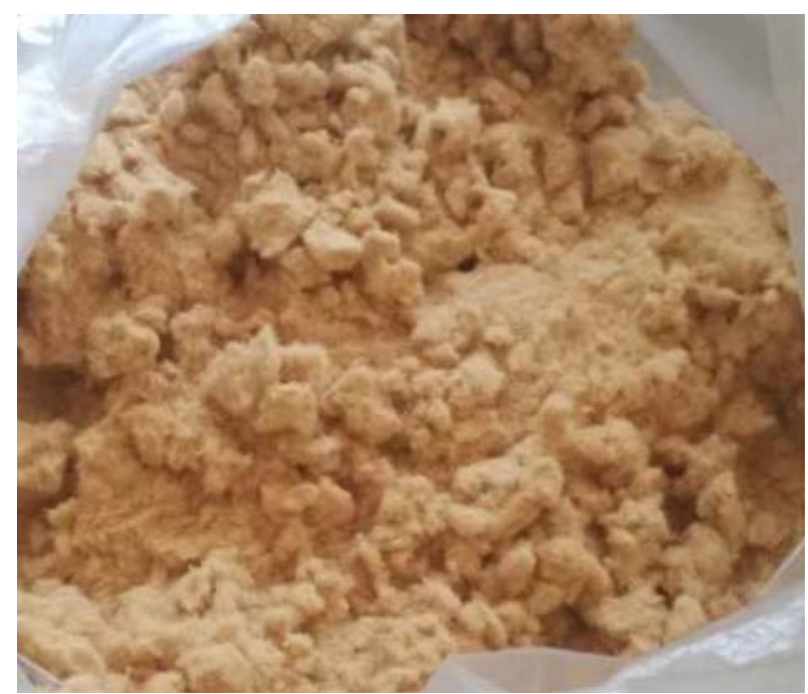

Fig. 1. Wooden fibers used in research

\section{Mixture proportions}

The mixture proportions of tested samples, which were prepared in five series of three samples, are shown in Table 1 . The first series was created only from mixture of water and building plaster. In the following four series wooden fibers were added to the mixture of building plaster and water in $7.50 \%$ dispersion at $2.50 \%$.

\section{Description of the test samples}

Each series was prepared in proportions of mixture shown in Table 1. For compressive test and flexur-

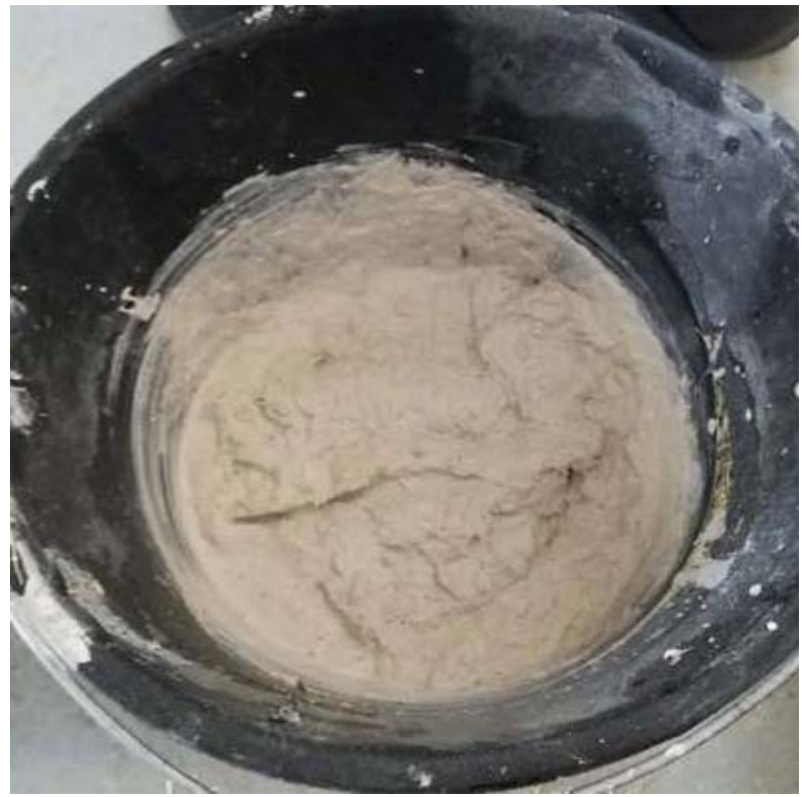

Fig. 2. Mixture of plaster with wooden fibers

al strength test there were created five series of three samples with dimensions $40 \times 40 \times 160 \mathrm{~mm}$. The samples were created in steel moulds for testing the mechanical properties of mortar and cement materials.

\section{Experimental part}

The samples were created in technical laboratory that is adapted to the production of experimental samples.

The mixing method was performed as follows:

1) The ingredients of each series were weighed in the amount shown in Table 1.

2) After weighing the dry ingredients were mixed and then mixed with $750 \mathrm{ml}$ of water for three minutes.

3) Steel moulds were filled by resulting mixture. All samples were placed on the vibration table and vibrated for one minute. The surface of samples was levelled to be smooth by the trowel.

4) Samples were removed from steel moulds after 24 hours and properly marked. Samples were left for 7 days in the test environment, dried at $40{ }^{\circ} \mathrm{C}$

Table 1. Percentage and weight proportions of tested series

\begin{tabular}{lccccc}
\hline & \multicolumn{2}{c}{ Plaster } & & \multicolumn{2}{c}{ Wooden fibers } \\
\cline { 2 - 3 } \cline { 5 - 6 } Series & $\begin{array}{c}\text { Percentage } \\
\text { proportions [\%] }\end{array}$ & $\begin{array}{c}\text { Weight } \\
{[\mathrm{kg}]}\end{array}$ & & $\begin{array}{c}\text { Percentage } \\
\text { proportions }[\%]\end{array}$ & $\begin{array}{c}\text { Weight } \\
{[\mathrm{kg}]}\end{array}$ \\
\hline 1 & 100.00 & 1.200 & & 0.000 & 0.000 \\
2 & 99.00 & 1.185 & & 1.250 & 0.015 \\
3 & 97.50 & 1.170 & & 2.500 & 0.030 \\
4 & 95.00 & 1.140 & & 5.000 & 0.060 \\
5 & 92.50 & 1.110 & & 7.500 & 0.090 \\
\hline
\end{tabular}




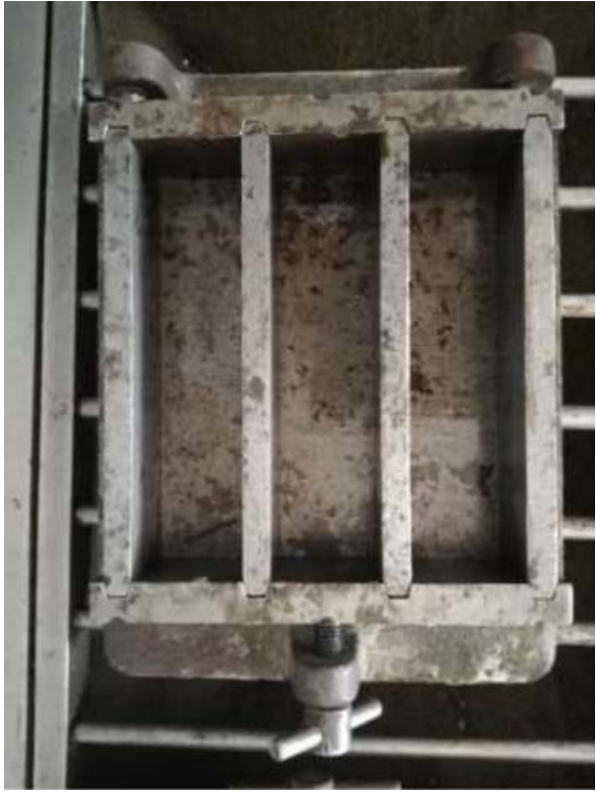

Fig. 3. Steel mould

to a steady weight. After drying samples were left in a laboratory environment, where they were cooled to room temperature [7].

\section{Results and discussion}

\section{Compressive strength and flexural strength}

The samples were tested at the material age of 7 days in compression and flexural strength test. Temperature and relative humidity of the indoor air during sample testing were $23.9^{\circ} \mathrm{C}$ and $48 \%$. Samples were weighed

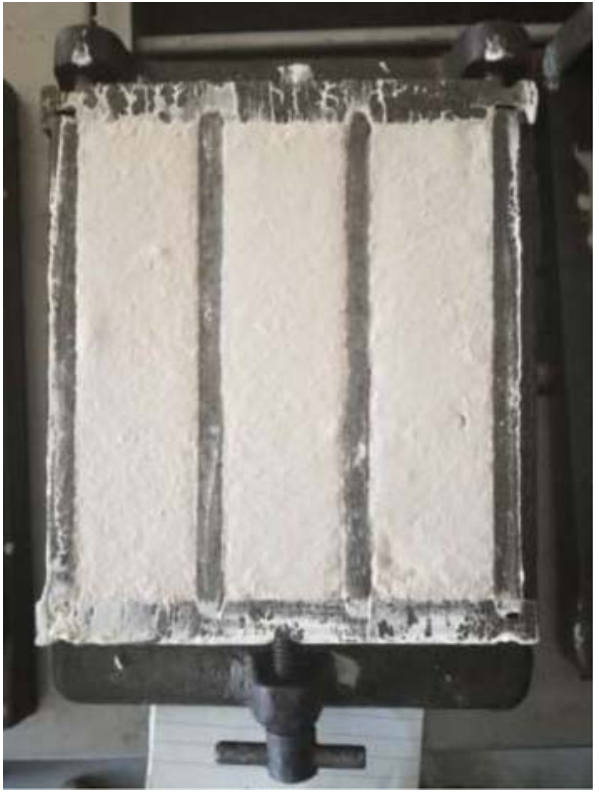

Fig. 4. Mixture of test specimens in test mould

before testing as is shown in Table 2. Test results are shown in Tables 3 and 4.

The weighed samples were placed in the press during testing in the order from the smallest proportion of wooden fibers to the biggest.

First, the samples were tested in flexural strength test. In this test, samples with low proportion of wooden fibers were totally damaged in their center, shown in Fig. 5, whereas samples with higher proportion of wooden fibers showed only cracks in the place of load impact by press roller. The biggest measured value of

Table 2. Weights of tested samples

\begin{tabular}{|c|c|c|c|c|}
\hline \multirow[t]{2}{*}{ Series } & \multirow{2}{*}{$\begin{array}{l}\text { Specification } \\
\text { samples }\end{array}$} & \multicolumn{2}{|c|}{ Percentage proportions } & \multirow{2}{*}{$\begin{array}{c}\text { Weight } \\
{[\mathrm{kg}]}\end{array}$} \\
\hline & & Plaster [\%] & Wooden fibers [\%] & \\
\hline \multirow{3}{*}{1} & $0_{1}$ & & & 0.308 \\
\hline & $\mathrm{O}_{2}$ & 100.00 & 0.00 & 0.306 \\
\hline & $0_{3}$ & & & 0.309 \\
\hline \multirow{3}{*}{2} & $1.25_{1}$ & & & 0.304 \\
\hline & $1.25_{2}$ & 99.00 & 1.25 & 0.303 \\
\hline & $1.25_{3}$ & & & 0.301 \\
\hline \multirow{3}{*}{3} & $2.5_{1}$ & & & 0.266 \\
\hline & $2.5_{2}$ & 97.50 & 2.50 & 0.266 \\
\hline & $2.5_{3}$ & & & 0.267 \\
\hline \multirow{3}{*}{4} & $5_{1}$ & & & 0.245 \\
\hline & $5_{2}$ & 95.00 & 5.00 & 0.234 \\
\hline & $5_{3}$ & & & 0.242 \\
\hline \multirow{3}{*}{5} & $7.5_{1}$ & & & 0.205 \\
\hline & $7.5_{2}$ & 92.50 & 7.50 & 0.203 \\
\hline & $7.5_{3}$ & & & 0.201 \\
\hline
\end{tabular}


Table 3. Flexural strength of the test samples

\begin{tabular}{|c|c|c|c|c|c|c|c|}
\hline \multirow[t]{2}{*}{ Series } & \multirow{2}{*}{$\begin{array}{l}\text { Specification } \\
\text { samples }\end{array}$} & \multicolumn{2}{|c|}{ Percentage proportions } & \multirow{2}{*}{$\begin{array}{l}\text { Flexural loading } \\
\quad \text { limit } f_{t}[\mathrm{~N}]\end{array}$} & \multirow{2}{*}{$\begin{array}{c}\text { Flexural } \\
\text { strength } \sigma_{t} \\
{\left[\mathrm{~N} \cdot \mathrm{mm}^{-2}\right]}\end{array}$} & \multirow{2}{*}{$\begin{array}{c}\text { Average value } \\
\text { of flexural } \\
\text { strength } \sigma_{t} \\
{\left[\mathrm{~N} \cdot \mathrm{mm}^{-2}\right]}\end{array}$} & \multirow{2}{*}{$\begin{array}{c}\text { Standard } \\
\text { deviation of } \\
\text { flexural strength } \\
\sigma_{t}\left[\mathrm{~N} \cdot \mathrm{mm}^{-2}\right]\end{array}$} \\
\hline & & $\begin{array}{c}\text { Plaster } \\
{[\%]}\end{array}$ & $\begin{array}{l}\text { Wooden } \\
\text { fibers [\%] }\end{array}$ & & & & \\
\hline & $0_{1}$ & & & 2248.000 & 5.260 & & \\
\hline \multirow[t]{3}{*}{1} & $0_{2}$ & 100.00 & 0.00 & 2336.000 & 5.466 & 5.212 & 0.229 \\
\hline & $0_{3}$ & & & 2099.000 & 4.912 & & \\
\hline & $1.25_{1}$ & & & 1828.000 & 4.278 & & \\
\hline \multirow[t]{3}{*}{2} & $1.25_{2}$ & 99.00 & 1.25 & 1670.000 & 3.908 & 4.427 & 0.496 \\
\hline & $1.25_{3}$ & & & 2177.000 & 5.094 & & \\
\hline & $2.5_{1}$ & & & 1697.000 & 3.971 & & \\
\hline \multirow[t]{3}{*}{3} & $2.5_{2}$ & 97.50 & 2.50 & 1749.000 & 4.093 & 3.944 & 0.133 \\
\hline & $2.5_{3}$ & & & 1611.000 & 3.770 & & \\
\hline & $5_{1}$ & & & 1127.000 & 2.637 & & \\
\hline \multirow[t]{3}{*}{4} & $5_{2}$ & 95.00 & 5.00 & 1108.000 & 2.593 & 2.635 & 0.033 \\
\hline & $5_{3}$ & & & 1143.000 & 2.675 & & \\
\hline & $7.5_{1}$ & & & 1030.000 & 2.410 & & \\
\hline \multirow[t]{2}{*}{5} & $7.5_{2}$ & 92.50 & 7.50 & 1080.000 & 2.527 & 2.348 & 0.177 \\
\hline & $7.5_{3}$ & & & 900.000 & 2.106 & & \\
\hline
\end{tabular}

the flexural loading limit was $2248 \mathrm{~N}$, measured on sample No. $0_{1}$. On the contrary the smallest value of the flexural loading limit was $900 \mathrm{~N}$, measured on sample No. 7.5. Other values are shown in Table 3.

Table 4. Compressive strength of the test samples

\begin{tabular}{|c|c|c|c|c|c|c|c|}
\hline \multirow[t]{2}{*}{ Series } & \multirow{2}{*}{$\begin{array}{c}\text { Specification } \\
\text { samples }\end{array}$} & \multicolumn{2}{|c|}{ Percentage proportions } & \multirow{2}{*}{$\begin{array}{c}\text { Compressive } \\
\text { loading limit } \\
\qquad f_{c}[\mathrm{~N}]\end{array}$} & \multirow{2}{*}{$\begin{array}{c}\text { Compressive } \\
\text { strength } \sigma_{c} \\
{\left[\mathrm{~N} \cdot \mathrm{mm}^{-2}\right]}\end{array}$} & \multirow{2}{*}{$\begin{array}{c}\text { Average value } \\
\text { of compr. } \\
\text { strength } \sigma_{c} \\
{\left[\mathrm{~N} \cdot \mathrm{mm}^{-2}\right]}\end{array}$} & \multirow{2}{*}{$\begin{array}{c}\text { Standard } \\
\text { deviation of } \\
\text { flexural strength } \\
\sigma_{t}\left[\mathrm{~N} \cdot \mathrm{mm}^{-2}\right]\end{array}$} \\
\hline & & $\begin{array}{c}\text { Plaster } \\
{[\%]}\end{array}$ & $\begin{array}{l}\text { Wooden } \\
\text { fibers [\%] }\end{array}$ & & & & \\
\hline \multirow{6}{*}{1} & $0_{11}$ & \multirow{6}{*}{100.00} & \multirow{6}{*}{0.00} & 25970 & 16.231 & \multirow{6}{*}{15.148} & \multirow{6}{*}{0.834} \\
\hline & $0_{12}$ & & & 23710 & 14.819 & & \\
\hline & $0_{21}$ & & & 25380 & 15.863 & & \\
\hline & $0_{22}$ & & & 24560 & 15.350 & & \\
\hline & $0_{31}$ & & & 21800 & 13.625 & & \\
\hline & $0_{32}$ & & & 24000 & 15.000 & & \\
\hline \multirow{6}{*}{2} & $1.25_{11}$ & \multirow{6}{*}{99.00} & \multirow{6}{*}{1.25} & 16350 & 10.219 & \multirow{6}{*}{11.067} & \multirow{6}{*}{0.651} \\
\hline & $1.25_{12}$ & & & 17650 & 11.031 & & \\
\hline & $1.25_{21}$ & & & 16370 & 11.231 & & \\
\hline & $1.25_{22}$ & & & 18860 & 11.787 & & \\
\hline & $1.25_{31}$ & & & 18880 & 11.800 & & \\
\hline & $1.25_{32}$ & & & 18130 & 11.331 & & \\
\hline \multirow{6}{*}{3} & $2.5_{11}$ & \multirow{6}{*}{97.50} & \multirow{6}{*}{2.50} & 13350 & 8.343 & \multirow{6}{*}{7.797} & \multirow{6}{*}{0.546} \\
\hline & $2.5_{12}$ & & & 12900 & 8.063 & & \\
\hline & $2.5_{21}$ & & & 12900 & 8.063 & & \\
\hline & $2.5_{22}$ & & & 12380 & 7.737 & & \\
\hline & $2.5_{31}$ & & & 10630 & 6.543 & & \\
\hline & $2.5_{32}$ & & & 12690 & 7.931 & & \\
\hline
\end{tabular}


Table 4. (cont'd)

\begin{tabular}{|c|c|c|c|c|c|c|c|}
\hline \multirow[t]{2}{*}{ Series } & \multirow{2}{*}{$\begin{array}{l}\text { Specification } \\
\text { samples }\end{array}$} & \multicolumn{2}{|c|}{ Percentage proportions } & \multirow{2}{*}{$\begin{array}{c}\text { Compressive } \\
\text { loading limit } \\
f_{c}[\mathrm{~N}]\end{array}$} & \multirow{2}{*}{$\begin{array}{c}\text { Compressive } \\
\text { strength } \sigma_{c} \\
{\left[\mathrm{~N} \cdot \mathrm{mm}^{-2}\right]}\end{array}$} & \multirow{2}{*}{$\begin{array}{l}\text { Average value } \\
\text { of compr. } \\
\text { strength } \sigma_{c} \\
{\left[\mathrm{~N} \cdot \mathrm{mm}^{-2}\right]}\end{array}$} & \multirow{2}{*}{$\begin{array}{c}\text { Standard } \\
\text { deviation of } \\
\text { flexural strength } \\
\sigma_{t}\left[\mathrm{~N} \cdot \mathrm{mm}^{-2}\right]\end{array}$} \\
\hline & & $\begin{array}{c}\text { Plaster } \\
{[\%]}\end{array}$ & $\begin{array}{l}\text { Wooden } \\
\text { fibers [\%] }\end{array}$ & & & & \\
\hline \multirow{6}{*}{4} & $5_{11}$ & \multirow{6}{*}{95.00} & \multirow{6}{*}{5.00} & 6780 & 4.237 & \multirow{6}{*}{4.233} & \multirow{6}{*}{0.086} \\
\hline & $5_{12}$ & & & 6720 & 4.200 & & \\
\hline & $5_{21}$ & & & 6780 & 4.237 & & \\
\hline & $5_{22}$ & & & 6650 & 4.156 & & \\
\hline & $5_{31}$ & & & 7060 & 4.412 & & \\
\hline & $5_{32}$ & & & 6650 & 4.156 & & \\
\hline \multirow{6}{*}{5} & $7.5_{11}$ & \multirow{6}{*}{92.50} & \multirow{6}{*}{7.50} & 5250 & 3.281 & \multirow{6}{*}{3.323} & \multirow{6}{*}{0.033} \\
\hline & $7.5_{12}$ & & & 5340 & 3.337 & & \\
\hline & $7.5_{21}$ & & & 5250 & 3.281 & & \\
\hline & $7.5_{22}$ & & & 5330 & 3.331 & & \\
\hline & $7.5_{31}$ & & & 5400 & 3.375 & & \\
\hline & $7.5_{32}$ & & & 5330 & 3.331 & & \\
\hline
\end{tabular}

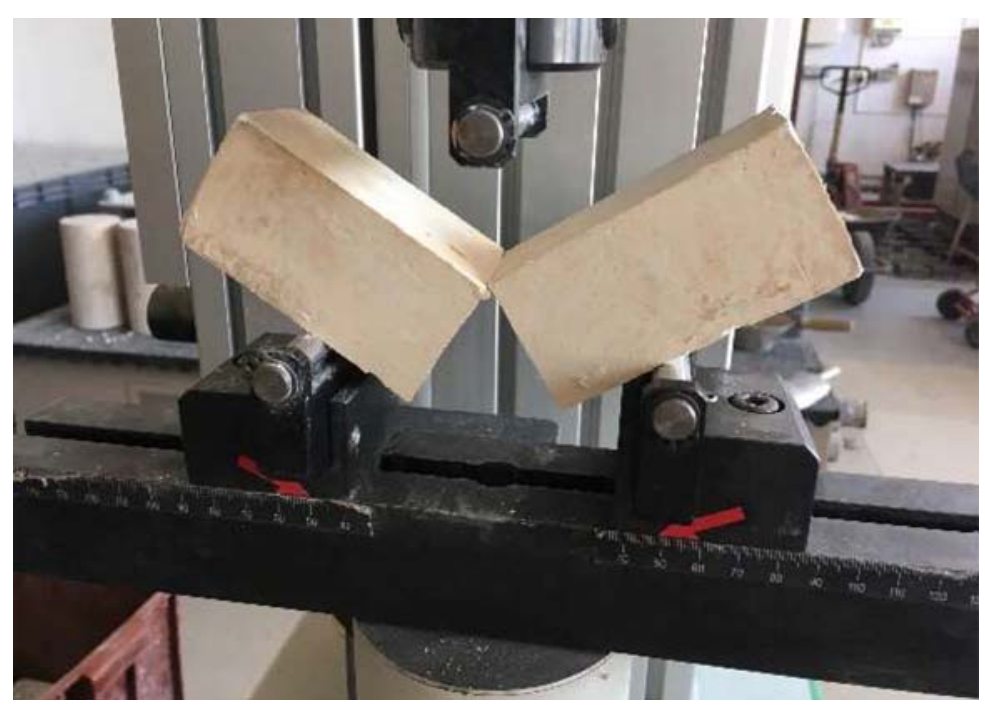

Fig. 5. Damage of sample No. $0_{1}$ after the flexural strength

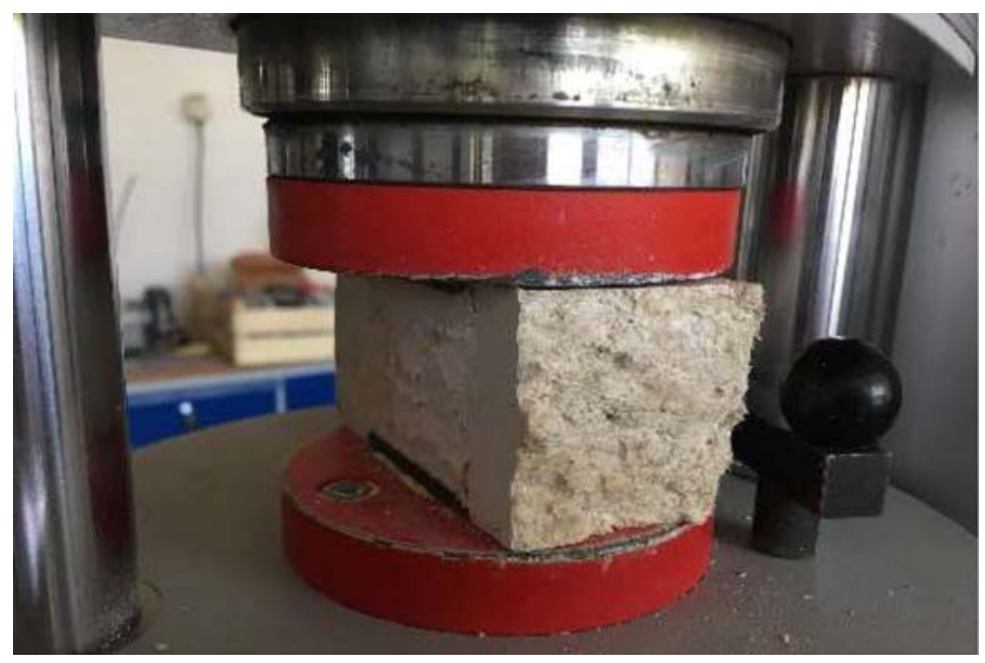

Fig. 6. The sample No. $7.5_{12}$ during the compression strength test 


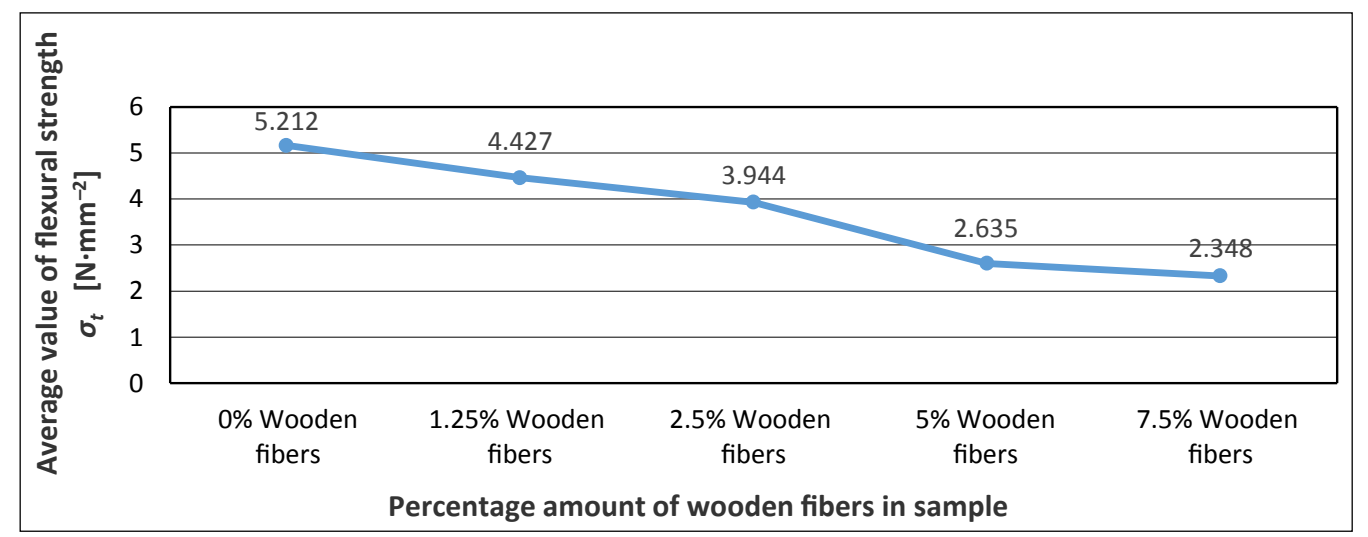

Graph 1. Average flexural strength

Calculation of flexural strength

$$
\sigma_{t}=0.00234 F,
$$

where

$\sigma_{t}-$ flexural strength $\left[\mathrm{N} \cdot \mathrm{mm}^{-2}\right]$

$F-$ average value of flexural strength [N], [7].

After the flexural strength test, half samples resulted from original samples and were marked by the proportion of wooden fibers content. For example, from the sample $0_{1}$ there were new samples $0_{11}$ and $0_{12}$, more in Table 4. These new samples were tested in compression strength test. Samples were placed in the press during testing in the order from the smallest proportion of wooden fibers to the biggest.

They were oriented so that the load was perpendicular to the direction of filling. The measured values are shown in Table 4.

The smallest strengths were shown by samples from series $5\left(7.5_{11} ; 7.5_{12} ; 7.5_{21} ; 7.5_{22} ; 7.5_{31} ; 7.5_{32}\right)$. The highest strengths were shown by samples from series 1 and sample number $1.25_{22}$ with value 11.79 $\left[\mathrm{N} \cdot \mathrm{mm}^{-2}\right]$. The measured values are shown in Table 4 .

\section{Calculation of compressive strength}

$$
\sigma_{c}=f_{c} / 1600,
$$

where

$\sigma_{c}$ - compressive strength $\left[\mathrm{N} \cdot \mathrm{mm}^{-2}\right]$

$f_{c}$ - maximum weight when test sample crush [N]

$1600-40 \times 40 \mathrm{~mm}$ is area of boards [ $\left.\mathrm{mm}^{2}\right]$, [7].

\section{Conclusion}

The results of the tests have shown that a larger amount of wooden fibers reduces compressive strength and flexural strength. The assumption that the wooden fibers reinforcement increases the flexural strength has not been confirmed. From the measured values it is clear that the reduction in compressive strength of the bend is linearly dependent on the proportion of wooden fibers. At $7.50 \%$ by weight of the wooden fibers, to the gypsum fraction, the compressive strength is reduced by $78 \%$ and the flexural strength by $55 \%$. The reason can be its insufficient mixing with plaster and water or joining of the wooden fibers into small clumps. To improve compressive strength, it would be advantageous to use thinner stalks and to improve flexural strength by a longer stalk. Increasing the strength of the tested composite may also affect the strength of the plaster. For the research, plaster of class G2 with a compressive strength of $2 \mathrm{MPa}$ was used. In the framework of further research, we would like to verify the effect of gypsum strength on the strength of the composite. The aim of further research will be

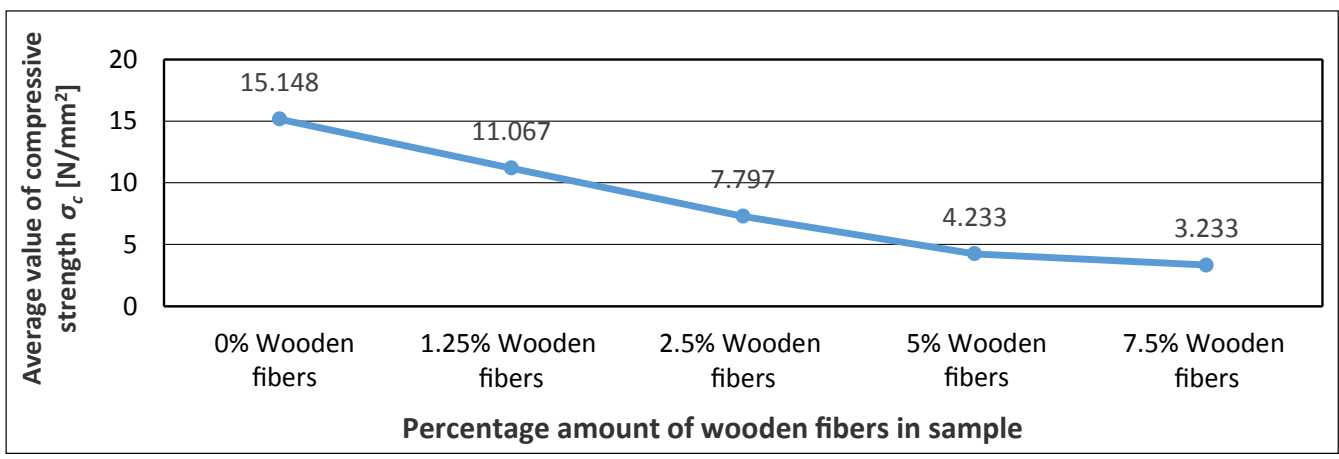

Graph 2. Average compressive strength 
to investigate the influence of the added binder on the strength parameters.

\section{Acknowledgements}

The work was supported by the Student Grant Competition VSB-TUO. Project registration number is SGS SP2018/124.

\section{References}

[5] Gomes M., Faria P., Gonçalves T. (2018), Earth-based mortars for repair and protection of rammed earth walls. Stabilization with mineral binders and fibers. Journal of Cleaner Production, 172, 2401-2414.

[6] Santos T., Nunes L., Faria P. (2017), Production of ecoefficient earth-based plasters: Influence of composition on physical performance and bio-susceptibility. Journal of Cleaner Production, 167, 55-67.

[7] Laborel-Préneron A., Aubert J., Magniont C., Tribout C., Bertron A. (2016), Plant aggregates and fibers in earth construction materials: A review. Construction and Building Materials, 111, 719-734.

[8] Gomes M., Gonçalves T., Faria P. (2016), Hydric behavior of earth materials and the effects of their stabilization with cement or lime: Study on repair mortars for historical rammed earth structures. Journal of Material in Civil Engineering, 28(7), 04016041

[9] McGregor F., Heath A., Shea A., Lawrence M. (2014), The moisture buffering capacity of unfired clay masonry. Building and Environment, 82, 599-607.

[10] Samson R. A., Houbraken J., Thrane U., Frisvad J. C., Andersen B. (2010), Food and Indoor Fungi. Utrecht: CBS-KNAW Fungal Biodiversity Centre, 390 p. (CBS Laboratory Manual Series). 